\title{
Stakeholder management in SME open innovation: interdependences and strategic actions
}

\author{
Ekaterina Albats* \\ LUT University, School of Business and \\ Management, Yliopistonkatu 34, 53850, Lappeenranta, Finland. \\ E-mail: ekaterina.albats@1ut.fi \\ Phone: +358503718771
}

\section{Allen Alexander}

University of Exeter Business School, Penryn Campus, Falmouth, TR10 9FE, UK

E-mail: $\underline{\text { A.T.Alexander@exeter.ac.uk }}$

\section{Maral Mahdad}

University of Copenhagen - Department of Food and Resource Economics, Section for Production, Markets and Policy Rolighedsvej 25, 1958 Frederiksberg C, Denmark.

E-mail: mahdad@ifro.ku.dk

\section{Kristel Miller}

Ulster University, Department of Management, Leadership \& Marketing, Shore Road, Newtownabbey, Co. Antrim, BT37 0QB, UK

E-mail: k.miller@ulster.ac.uk

\section{Ger Post}

Fontys University of Applied Sciences, School of Business Management, Education and Technology, Rachelsmolen 1, 5612 MA, Eindhoven. The Netherlands

E-mail: g.post@fontys.nl

*- corresponding author

Acknowledgement: This research forms a part of a larger European project - INSPIRE (H2020 project under grant agreement No 691440 - INSPIRE). The INSPIRE project is a Coordination and Support Action funded by the European Commission, which aims to professionalize Open Innovation (OI) processes within Europe's SMEs (for more information please see www.inspire-smes.info). 


\begin{abstract}
This research explores how small and medium-sized enterprises (SMEs) manage external stakeholders during open innovation (OI) processes. To date, extensive literature has explored OI within large organisations, however, there is limited understanding of how SMEs can strategically manage stakeholders during different stages of OI projects. Using a multigrounded theory approach, 11 cases of SME OI projects were analysed across four regions within Europe. The findings reveal a wide range of primary and secondary stakeholders with varying levels of power and dependency were leveraged across the different stages of the OI projects. A model is presented which advances knowledge on how to map, analyse and manage stakeholders strategically in a SME-OI context. Our research helps advance theory on SMEOI stakeholder management processes and reveals appropriate stakeholder management strategies, which will assist SME managers in alleviating the SME-OI paradox.
\end{abstract}

Key words: Stakeholder theory; Open innovation; SME, Interdependences; Strategic actions, stakeholder management 


\section{Stakeholder management in SME open innovation:}

\section{interdependences and strategic actions}

\section{Introduction}

The interest in open innovation (OI) continues to grow since its introduction by Chesbrough (2003). In an increasingly globalised economy, organisations rely on external knowledge as a source of competitive advantage (Lee et al. 2010; Popa, Soto-Acosta, \& Martinez-Conesa, 2017). Vast amounts of literature have explored OI processes (Bogers et al., 2017; West \& Bogers, 2013), but to date, these studies have predominantly focused on large firms. Therefore, research on OI in small and medium sized enterprises (SMEs) is pertinent (Vanhaverbeke, 2017). SMEs rely on external capabilities to overcome 'liabilities of smallness' (Pullen et al., 2012), however, this presents a paradox since SMEs lack resources to leverage key networks (Ortega-Argilés, et al. 2009).

OI relies upon effectively managing relationships with external actors (Popa et al., 2017), however, conflicts arise due to mismatched objectives, strategic/organisational fit or power imbalance (Spithoven et al., 2012). Huggins and Thompson (2015) identify the need to explore 'how' stakeholder relationships are managed in OI. Furthermore, Limaj and Bernroider (2017) identify that the knowledge on stakeholder management in a SME-OI context remains very limited and requires further development. Accordingly, this research addresses these limitations by applying a stakeholder lens to explore how SMEs manage external stakeholders during OI. We begin by introducing the different dimensions of SME-OI, before deriving our stakeholder-based theoretical framework. We then present our methodological rationale and discuss our key findings and implications. 


\section{Open Innovation within SMEs}

\subsection{Defining open innovation}

Open innovation (OI) is rooted in various established academic literatures (Cohen \& Levinthal, 1990; Jeffrey \& Dyer, 1998; Teece, 1986), creating a challenge in distinguishing OI from 'business as usual' (Trott \& Hartmann, 2009). In conceptual terms, authors have debated between concepts (and phenomena) such as: closed vs. open innovation (Huizingh, 2011); open business model (Weiblen, 2014) vs. ('ordinary') business model (Burmeister, Lüttgens, \& Piller, 2016) and open innovation vs. open source (Jones, 2013). To aid clarity, Chesbrough and Brunswicker (2014) classify OI activities by two dimensions: the knowledge flow' direction (inbound vs. outbound) and the compensations along this flow (pecuniary vs. nonpecuniary).These two dimensions have been used to form a $2 \times 2$ matrix of 'open innovation' activities (Chesbrough \& Brunswicker, 2013). In line with this classification, Chesbrough and Bogers (2014, p. 27) define OI as a 'distributed innovation process based on purposively managed knowledge flows across organizational boundaries, using pecuniary and nonpecuniary mechanisms in line with each organization's business model'.

However, engaging in OI does not automatically mean that an organisation has an open business model. Frankenberger, Weiblen, \& Gassmann (2014) use the classic case of "P\&G Connect \& Develop" program to illustrate how ideas/technologies acquired from external parties can create value in an 'open' way, however, unless this value is captured jointly, it is not an open business model (Weiblen, 2014). A combination of open R\&D and open business models can be illustrated by the case of Valve (a computer game producer) who allows external actors to develop games based on their own technology, which results in value co-creation, where both Valve and external actors benefit from community-driven innovation (Jeppesen \& Molin, 2003). Openness is an integral part of Valve' value-creation and capture logic, which 
makes it an example of open-process, open-outcome (Huizingh, 2011), consequently leading to an open business model.

Despite ambiguity in OI terminology (Teplov, Albats, \& Podmetina, 2018), cognitive abstraction identifies integral components to be considered when exploring SME OI processes. Firstly, the 'process of openness' which is commonly seen as collaboration 'breadth' (number of external collaborating parties/stakeholders) and 'depth' (collaboration intensity) (Laursen \& Salter, 2006). Secondly, the 'innovation outcome' itself which reflects the 'successful exploitation of new ideas' (Adams, Bessant, \& Phelps, 2006, p. 22).

\subsection{Open innovation in SME context}

It is evident from prior research that engaging in OI helps firms to access ideas, knowledge and technologies from relevant stakeholders in their ecosystems (Spithoven et al. 2012). OI projects reduce $\mathrm{R} \& \mathrm{D}$ costs, help to spread risk and bring innovations to market faster (Chesbrough, 2010 Xie, Wang, \& Zeng, 2018). However, firm size has been found to impact OI practices and outcomes (Pullen et al., 2012). Han et al., (2012) suggest that large firms' OI typically occurs during the R\&D stage, whereas SME-OI occurs in later stages to access market/business intelligence. Hewitt-Dundas and Roper (2018) identify that levels of OI in small firms are sub-optimal due to a paucity of OI capabilities. The current literature on SMEOI is thin and fragmented (Popa et al, 2017; Spithoven et al. 2010). In particular, there is a lack of understanding of the stakeholder dynamics prevalent in SME-OI processes (Gould, 2012) despite external stakeholder relationships being fundamental for OI.

Vanhaverbeke and Cloodt (2014) identify that new theoretical lenses are needed to explain the OI phenomenon, thus, we present stakeholder theory as a tool to help better understand how stakeholder relationships can be leveraged during SME-OI processes. 


\subsection{Approaches in identifying and mapping stakeholders in SME-OI processes}

To understand stakeholder's behaviours during SME-OI, process mapping is needed (Miles, 2017). Freeman (1984) proposes stakeholders can be categorised as being primary (engaged in direct economic transactions and thus affected by the focal organisation) or secondary (not engaged in direct economic transactions but still affect/are affected by the focal organisation). Darnall and Henriques (2010) further identify that primary stakeholders can be external to an organisation i.e. value-chain stakeholders (customers, suppliers) or internal (company' management and non-management employees). Secondary stakeholders can be grouped into societal (environmental groups, community organizations, labour unions, and industry/trade associations) and regulatory stakeholders (authorities) (Darnall and Henriques, 2010). Darnall and Henriques (2010) identify that regulatory and value-chain stakeholders impact smaller firms more than larger firms, whereas pressure from societal stakeholders impact large and small firms in similar ways. Prior research identifies that smaller firms are able to respond to external stakeholder pressures with greater vigour, due to their resource scarcity, stronger innovation propensity, simplified decision-making, smaller information asymmetries and efficient communication which has been found to aid collaboration success (Darnall \& Henriques, 2010; Glynn, 1996; Wickert, Scherer, \& Spence, 2016). Figure 1 synthesises prior OI research to provide our overview of the potential external stakeholder categories that SMEs may engage with.

Figure 1

Due to the significance of stakeholder firm size (Pullen et al. 2012), Figure 1 also distinguishes between large enterprise (LE) partners and other SME partners as primary stakeholders. Referring to the inner circle, primary stakeholders include; $L E$ or $S M E$ stakeholders who may be within the focal SME's immediate value-chain (suppliers or customers) (Darnall \& Henriques, 2010) or stakeholders from other industries. Lead user's 
(individuals or $\mathrm{B} 2 \mathrm{~B}$ customers), who can be a valuable source for SME' user centric innovations. Individual experts and/or professional communities (including online forums), who have been found to be a primary source of knowledge for SMEs (Presenza \& Meleddu, 2017; Van de Vrande et al., 2009). Finally Public sector research (PSR) institutions/ universities have also been deemed to be primary stakeholders as they provide valuable knowledge which can help SMEs overcome their liabilities of smallness (Brunswicker \& Vanhaverbeke, 2014).

The outer-circle shows secondary stakeholders who are not considered to be directly involved in the OI process, but can influence/be influenced (Chesbrough, 2006; Freeman, 1984). These are: government, as a regulatory body or funder of SME OI activities (Presenza \& Meleddu, 2017); private investors, who provide financial resources and seek financial returns (Vanhaverbeke, 2017); business incubators and accelerators, who can help support SME growth and development (Vanhaverbeke, 2017); and competitors who have been found to be both collaborators and a source of co-opetition (Bogers et al., 2017).

To determine the point at which stakeholders may interact, we utilise Bessant and Tidd's (2015) innovation process four-stage model: recognising the opportunity; finding the resources; idea development and capturing value. These four stages are presented at the very inner circle of figure 1. OI is dynamic therefore any of the stakeholders can engage and stop their collaborations at any stage (Van de Vrande et al., 2009), which is illustrated by the arrows in figure 1.

External stakeholder engagement is a dominant differentiator between OI and traditional innovation (Laursen and Salter, 2014). However, Graham (2017, p. 16) argues that "internal stakeholders' perceptions of external pressures is an important consideration as it is often their perceptions that lead them to respond in particular ways" [i.e. the strategies undertaken by companies reflect an internal stakeholder perspective (Buysse \& Verbeke, 2003; Graham, 
2017)]. As suggested by Darnall and Henriques (2010), the smaller the company, the more direct the relationship, thus, our study considers the role of internal stakeholders through the prism of a company's strategic actions, and more directly focuses on understanding external stakeholder relationships and influence during OI. Whilst figure 1 aids stakeholder categorisation, it does not help to understand how stakeholder relationships can be managed during OI, thus we further explore stakeholder theory to aid our theory development.

\subsection{Exploring stakeholder interaction and relationships}

A key challenge facing SMEs undertaking OI is how they mitigate risk from external engagement (Kaufmann \& Shams, 2015). With smaller financial reserves and closer relationships between revenue and cash-flow, SMEs are more sensitive to delays and cost overruns in OI (Van de Vrande et al., 2009). However, prior research has found contradictory evidence regarding breadth of stakeholder co-creation and innovation performance (Markovic \& Bagherzadeh, 2018). Therefore, it is important to understand the impact that various stakeholders can have on OI. Friedman and Miles' (2002) draw on research by Archer (1995) and present a socially-constructed typology for understanding complex stakeholder relationships which is presented in Table 1.

\section{Table 1}

Friedman and Miles (2002) typology can be applied to the SME-OI context to allow identification of the risk arising from relationships by categorising them as compatible or incompatible. This helps to identify if stakeholders will work effectively together to achieve shared innovation goals or generate collaborative tensions and hinder each other. Furthermore, stakeholders can be evaluated in accordance to the type of relationship which is deemed as either necessary (a stakeholder provides an essential resource) or contingent (not inherently integrated, but with the potential to influence outcomes e.g. government). Depending on the characteristics of the stakeholder partnership, Friedman and Miles (2002) propose four 
configurations, which each require a particular situational logic and aid the development of appropriate strategic actions (see Table 1):

- Configuration A - represents firms' and external stakeholders' mutual dependence on a key resource. They defend the OI relationship - an ideal scenario for OI.

- Configuration B - represents firm-stakeholder incompatibility (due to e.g. cultural differences) but resource dependency exists if they cannot seek alternative sources, and management strategy embraces opportunism to acquire and lever resources.

- Configuration $\mathrm{C}$ - represents firm-stakeholder incompatibility however, they are pursuing the same goals, e.g. competition for resources/funding. This competition can lead to elimination of one of the parties (a high-risk strategy for SME-OI).

- Configuration D - represents firm and stakeholders who have resources that each other need, but their organisational culture, and objectives differ. Both stakeholders must be willing to embrace a relationship of mutual concession, which leads to compromises that facilitate relational longevity (Friedman \& Miles, 2002).

To further improve the fit of Friedman \& Miles' (2002) work and stakeholder theory to the OI context, we have synthesised Frooman's (1999) model in order to categorise stakeholder power and dependency during OI (Table 2).

Table 2

Frooman's (1999) model has been used previously to inform how organisations can manage multiple stakeholders (McAdam, Miller, \& McAdam, 2016), but to date has been unproven in terms of it's suitability for SME-OI context. Overall, it is clear that stakeholder theory can help advance knowledge and practice of SME OI. Accordingly, we identify two key research questions.

RQ1: What role do external stakeholders play at varying stages of the SME OI process? 
RQ2: How can SMEs manage various types of external stakeholder relationship configurations during open innovation processes?

\section{Research Methodology}

A qualitative case study was adopted to explore SME interactions with diverse stakeholders. This responds to calls for context rich, comparative studies to aid theoretical and empirical advancement (Limaj \& Bernroider, 2017). Cases were selected from different regions (Denmark, Finland, The Netherlands and Norway), which are comparable through their levels of innovation and sharing similar characteristics such as the key role SMEs play in each region's employment and economic development (European Commission, 2017). To aid theory development and analytical generalisation, our primary inclusion criteria was informed by a combination of internet searches and academic publications relating to the particular regions plus engagement with professional networks and communities such as the Open Innovation Network $^{1}$ and INSPIRE ${ }^{2}$. We then adopted a variation approach to target SMEs from varying sectors (manufacturing/services), technology-intensity (high/medium/low) and those engaging with various stakeholders. This initial search resulted in 30 cases. Selection then followed a combination of theory-based and criterion sampling strategies (Patton, 1990), which included company size ${ }^{3}$; innovativeness/novelty of their offering and collaboration with external stakeholders in value creation/capture. Secondary data for each case was then double-checked against the set criteria and any cases which did meet the criteria were eliminated. The companies were then contacted, resulting in 11 who agreed to take part. Table 3 provides an overview of the cases.

Table 3

\footnotetext{
${ }^{1}$ See www.oi-net.eu

${ }^{2}$ See www.inspire-smes.info

3 in terms of the staff headcount and turnover - see (European Commission, 2018) for a definition of SME 
In-depth interviews were carried out with the CEOs/founders and managers between August 2016 and May 2017. A semi-structured interview guide was used to identify stakeholder engagement and management strategies at each of the four stages of the innovation process, using a critical incident technique (Cassell \& Symon, 2004). Interviews averaged 50 minutes, were audio recorded and transcribed verbatim. Interview data was supplemented with secondary data sources (press-releases, blog posts, financial and administrative information retrieved from Amadeus database).

The data was analysed utilising a multi-grounded theory approach (Goldkuhl \& Cronholm, 2010, 2018), which combines inductive (data-driven) and deductive (theory-driven) reasoning (Glaser, 1992) and implies three types of grounding processes (Goldkuhl \& Cronholm, 2010):

- Empirical grounding: data-driven, inductive, pattern coding and conceptual refinement, (see Annex 1), followed by empirical validation (see Table 4 and Annex 2);

- Theoretical grounding: comparing our empirical findings against the existing literature on innovation, SME-OI and stakeholder management (theoretical matching - Annex 2);

- Internal grounding: evaluation of theoretical cohesion, concepts and relations between them (results and discussion sections).

This analysis process resulted in open codes, first order categories and second order themes Table 4 provides a synopsis of this process.

Table 4

\section{Results}

The cases varied from very open, non-pecuniary crowd-science initiatives (case B), crowdsourcing (case C), networking with experts (cases B, C, G, H, I), co-innovation with universities (cases A, E, F, J, K) towards pecuniary OI heavily relying on risk-sharing (cases A, D, E). All of the studied cases represent mainly inbound OI with several having also a 
coupled OI logic (cases B, C, F, H, I, K). Only a few cases had some outbound practices applied (cases A, G, J spin-outs, case I participation in standardization and case $\mathrm{K}$, joint venture).

To address our research questions, we utilise Figure 1 as an interpretative tool and take each stakeholder group in turn and discuss how the respective SMEs managed external relationships during the different OI process' stages. See Annex 2 for summary of the results.

\section{Results}

\subsection{Primary stakeholders}

\section{Large Enterprises as customers}

In cases $\mathbf{D}, \mathbf{E}, \mathbf{F}, \mathbf{G}$ and $\mathbf{K}$, LEs are customers providing market knowledge for the SMEs. LEs facilitated access to greater client networks (Cases D, G) which benefited the opportunity recognition and value capture stages, and helped gain access to funding for idea development (Cases $\mathbf{D}, \mathbf{F}, \mathbf{G}, \mathbf{K})$ at the finding resources stage of the innovation process. This led to SMELE dependency relationships (Frooman, 1999), where the LE exerted stakeholder power. For example case D's manager identified: “They were and still are our biggest customer... They said 'we want the things to go that way'... We needed... some funding for product development ... That was one of the key reasons to see it as a good opportunity. " It was identified that many LEs try to entice SMEs into contractual agreements which promise 'exclusive' collaboration. However, this was found to hinder the SMEs future developments through constraining their ability to innovate and lock-in SME' resources. However, it was clear that the LEs were committed to the success of their SME partners, thus a symbiotic relationship existed. It was reported that LEs did not exert their power in a negative way, resulting in configuration A which illustrates an effective OI partnership (Annex 2). However, challenges did exist, where the SMEs did have to adjust their operations to meet the LE clients' demands. In case E, the LE-partner required statements of credibility and adherence to stringent quality standards. Furthermore, Case $\mathbf{E}$ identified that SMEs may need to start small with their OI collaborations 
to develop their credibility: "At the start we were mainly working with smaller companies and when we got enough credibility... then the big ones started to get interested in our products".

\section{SMEs as customers or suppliers}

Other SMEs being the focal firms' customers were found to be valuable at the opportunity recognition phase. Compared to the LEs, partnerships with other SMEs had a significantly lower degree of interdependency. In cases $\mathbf{G}, \mathbf{H}$ and $\mathbf{I}$, the focal SMEs informally identified opportunities through SME customer interactions. Such opportunistic learning helped them to create unique value propositions in the new business domains. For example, Case $\mathbf{G}$, while developing a service for small-sized companies, shifted its business focus from digital marketing to software services. Case $\mathbf{H}$, originally operating in management consulting, identified an opportunity for a niche focus towards consulting on digital business modelling due to demand from small-sized customers.

In cases $\mathbf{E}$ and $\mathbf{I}$, OI with other SMEs occurred in the innovation development stage. These cases developed supplier relationships with other SMEs to overcome internal skill limitations (i.e. to avail of prototyping in Case $\mathbf{E}$ and digital learning tools in case $\mathbf{I}$ ). In these scenarios, the high level of competency of the supplier created SME dependency. The focal SMEs were mitigating this risk through assuring reciprocity for the SME-supplier either through direct financial gains or indirect strategic interest in the joint development. This led to partners adopting a protectionist strategy (Friedman \& Miles, 2002) to safeguard their alliance. Case $\mathbf{E}$ was experiencing intense competition from a large player and developed collaborations with their SME-customer during the value capture stage. This resulted in customer power; where consequently, the firm invested resources to develop this relationship ('we hired a private airplane..., flew directly to meet the customer' in the team of 'eight people'). The focal firm and SME customer partner were a good fit due to similar processes, culture and 
commitment which resulted in a compromise relationship (Friedman and Miles, 2002) which helped to facilitate value co-creation and elimination of the competitor.

\section{Experts and expert communities}

Experts and expert communities played a key role across different stages of the SMEs' innovation process: opportunity recognition (cases $\mathbf{A}, \mathbf{B}, \mathbf{C}, \mathbf{F}, \mathbf{H}$ ), finding complementary capabilities/resources $(\mathbf{B}, \mathbf{F})$, product/service development stage $(\mathbf{B}, \mathbf{F}, \mathbf{H})$, and value capture stage $(\mathbf{B}, \mathbf{F}, \mathbf{G})$. In all the cases involving experts $(\mathbf{A}, \mathbf{B}, \mathbf{C}, \mathbf{F}, \mathbf{G}, \mathbf{H})$, stakeholder power was in place (Frooman, 1999). The experts appeared to be motivated to contribute by their professional interest in the SME developments as highlighted by case B: "they love to contribute. If you acknowledge their expertise and the fact that they know more than you do then, yeah people are extremely helpful when it comes to sharing”. However, challenges did emerged at the stages of opportunity recognition and idea development (Annex 2). At the idea development stage, cases $\mathbf{B}$ and $\mathbf{H}$ identified that access and help from experts within online communities appeared required a reciprocal contribution: “...we used their open source, parts and components, and added our own, and then we also shared their community... we published our 3D printing files and the specs" (Case B). The SMEs and experts both co-created value but also pursued their own interests. Consequently, the SMEs did not use a single configuration, but used a combination of A \& D configurations, where the parties defended the collaboration but also had to compromise.

\section{Lead users $(B 2 B / C)$}

Cases $\mathbf{B}$ and $\mathbf{C}$ engaged with individual users and the other cases partnered with B2B customers (D, E, H, I, J, K). The case companies engaged their lead users to develop their innovation concept and to test their products (cases $\mathbf{B}, \mathbf{C}, \mathbf{D}, \mathbf{E}, \mathbf{K})$ and services $(\mathbf{H}, \mathbf{I}, \mathbf{J})$. The users were often self-motivated to become OI partners. For example, within case $\mathbf{B}$, the users were even paying a fee to be a part of the product development. Despite this, the users were 
deemed to be powerful since their contributions helped develop the requirements for the product/service. This led to high levels of interdependency. In the B2B cases $(\mathbf{D}, \mathbf{E}, \mathbf{H}, \mathbf{I}, \mathbf{J})$, users had a choice of other partners (the SME' competitors), which led to users' stakeholder power. The SMEs had to compromise on the timeframes expected by lead users and exerted strategies to resolve these tensions, such as incentives (i.e. inviting the lead users to an advisory board (cases B, H) or a joint venture $(\mathbf{J})$ ). Referring back to Friedman \& Miles (2002), the SMEs-users relationships reflect not only opportunism (configuration B) with loose ties, but also demanded compromises (configuration D) and agility (see Annex 2).

\section{Public Sector Research (PSR) and Universities}

Public research institutions (PSR) (cases A, B, G) and universities (cases A, B, E, F, I, $\mathbf{J}, \mathbf{K})$ were found to be a valuable source of knowledge within the innovation development stage. However, challenges existed due to varying organizational objectives, processes and time frames: "They [university] have good ideas, but they are not always commercially feasible... So, you need a certain filter... of understanding what is commercially feasible..." (case E). The SMEs relationships with this stakeholder demonstrated necessary incompatibility, requiring compromises.

Cases $\mathbf{B}, \mathbf{E}$ and $\mathbf{J}$ utilised the academic background of their employees to help foster relationships with universities and PSRs. Cases A, E, F strategically targeted academics with business acumen (necessary compatibility) and those who were entrepreneurial to form joint research-based spin-outs. In case F, this strategy led to difficulties during co-creation of the concept. The focal SME and academic developed differing visions which resulted in the university setting up a new competing spin-out thus shifting from necessary compatibility to contingent incompatibility. 


\subsection{Secondary stakeholders}

\section{Government}

Government typically played a supporter' role in the SMEs' OI processes though the provision of co-financing during the finding the resources and idea development stages. Nonfinancial forms of government participation were found in cases $\mathbf{C}$ and $\mathbf{I}$, particularly in the idea development stage. In case $\mathbf{C}$, the city municipality representatives participated in the product development phase as proxy-users and commissioning agents. In case I, the European Standardisation Agency contributed to the SME's service design and value creation. Government was found to exert stakeholder power in these two cases, through defining regulations and standards. SMEs dealing with government as a secondary stakeholder applied strategies of compromise where they invested resources to access government co-financing and ensure regulations and imposed standards were met.

\section{Business incubators/accelerators}

Business incubators/accelerators were secondary stakeholders, providing external knowledge at the idea development stage (case B) and enabling the SMEs value capture strategies $(\mathbf{B}, \mathbf{C}, \mathbf{F})$. For this stakeholder, the SMEs applied a combination of opportunistic and compromising strategies. For example, participation in the programmes was voluntary, thus lacking dependency. However, the accelerator/incubator community did demand a reciprocal contribution (peer sharing of knowledge/advice) where the case SMEs had to find the right balance between knowledge sharing and disclosure.

\section{Investors}

Many of the cases were reliant on investors to provide finance $(\mathbf{A}, \mathbf{B}, \mathbf{E}, \mathbf{F}, \mathbf{G})$ at finding the resources stage. However, the short-term outlook of investors was reported to be a key challenge for cases $\mathbf{A}$ and $\mathbf{E}$. They identified that investors often demanded short-term rewards rather than support a longer-term strategy. This resulted in the need to integrate short-term 
goals to satisfy investors. It was found that in cases where the use of investors was unavoidable, control of their business was ensured through adopting a portfolio investment strategy which involved combining business angels, corporate venture capital, investment agents, getting new shareholders on board, and attracting loans. This resulted in both a defensive and compromise strategy being utilised to manage stakeholder relationships.

\section{Competitors}

SMEs-competitors relationships were grounded on contingency and indirect agency. For example, case I acquired the only competitor (another SME) to become the market leader. Case E was successful in persuading the competitor's staff to become part of the new organisation. Therefore, at the opportunity recognition phase, the SME assured its market leadership, which eventually contributed to idea development (with additional expertise acquired) and value capture (competitor elimination).

As seen from the findings, each of the SME-stakeholder relationships have specific characteristics depending on the SME' innovation process stage (Annexes 2 and 3). Contextual influences surrounding the SME-stakeholder engagements led to multiple stakeholder relationship configurations, which were dynamic (changed throughout the duration of the innovation process) and required elastic (combined) stakeholder management strategies for each stakeholder type (configurations with “/” and "\&” signs in Annex 2).

\section{Discussion}

OI can present many opportunities for resource constrained SMEs (Brunswicker \& Vanhaverbeke, 2014; Van de Vrande et al., 2009). Yet prior research has not provided a clear understanding of the stakeholder dynamics during SME-OI processes (Gould, 2012; Limaj \& Bernroider, 2017). Our findings identify a range of primary and secondary stakeholders engaged across various stages of the OI process. Primary stakeholders provided essential 
knowledge and resources helping the SMEs to enhance their competitive advantage. Large enterprises were found to be valuable at all four stages of the innovation process which contrasts with prior research which identifies them to be most valuable at the later stage of value capture (i.e. Hossain \& Kauranen, 2016; Van de Vrande et al., 2009). Other SMEs were found to be helpful at every stage except for the 'finding the resources' stage due to their own resource constraints. Lead users, universities and experts were found to be beneficial to aid idea development, with experts also aiding opportunity recognition. The findings revealed that although secondary stakeholders were not directly involved in SME-OI processes, their role was vital through the provision of financial resources (investors, government), idea generation (government, business incubators and accelerators), identification of market opportunities (competitors) and the development of skills to capture value (business incubators/accelerators).

Our findings suggest that in addition to having 'liabilities of smallness' in OI, SMEs also leverage size advantages, which compliments research by Rothwell and Dodgson (1991). Annex 3 presents a framework, which outlines not only the liabilities, but also the virtues of smallness in relation to each stage of the innovation process and specific stakeholders engaged. We identify that at the opportunity recognition stage, SMEs are not only vulnerable due to their dependency on large enterprises or experts, but are also empowered (as proposed by Badillo, Galera, \& Moreno Serrano, 2017; Dooley, Kenny, \& Cronin, 2016). For instance, in the SMELE relationship, the SMEs' unique idea or technology may become a knowledge source for an innovation within a LE, which makes the LE interested in (if not dependent on) the SMEs success. However, concurring with prior research (i.e. Olander, Hurmelinna-Laukkanen, \& Mähönen, 2009; Street \& Cameron, 2007), the cases highlight the risk of lock-in or strategic drift (Tidd, Bessant, \& Pavitt, 2001) when SMEs collaborate with LEs. A notable advantage was reported during SME-expert engagement, where the SME's propensity for informal 
collaboration and an absence of bureaucratic barriers (Rothwell, 1994) made it easier for the SMEs to engage with experts.

When 'finding resources', SMEs were found to overcome resource limitations through engagement with LEs and investors. At this stage, firm size was considered a benefit if seeking governmental support, where firm size becomes an eligibility criteria (Radas, Anić, Tafro, \& Wagner, 2015; Wren \& Storey, 2002). Similarly, at the idea development stage, firm size was identified as being an eligibility criteria for participating in certain business acceleration/incubation programs; a source of 'soft' support essential for SMEs (Wren \& Storey, 2002). The case SMEs leveraged customers to co-create ideas which was in contrast to their relationship with LEs which oriented more towards formal market research (Yeaple, 1992). However, LEs can financially invest more on innovation, have more power over suppliers to engage in new developments and encourage cost reductions (Harryson, 1997). Finally, the virtues of smallness make SMEs more compatible with other SMEs in terms of organizational culture and processes (Rothwell, 1994; Rothwell \& Dodgson, 1991), which empowered the case firms at the stages of idea development and value capture.

Whilst prior research identifies that SMEs often do not engage in OI due to a lack of trust or fear of losing power (Bogers et al., 2017), our findings identify that engaging in OI relationships that are heavily imbalanced in terms of partners size, resources or power should not necessarily be avoided. Many of the cases found that implementing contractual agreements, which clearly outline stakeholder roles and avoid lock-in meant that they were able to be on a level playing field with larger organisations.

Finally, our findings reveal that whilst stakeholder tools are useful to understand SMEOI relationships and management strategies, these tools are not agile enough to reflect all of the contextual factors at play during SME-OI processes. However, our study did find common themes across the cases, where the varying motivations of different external stakeholders led 
to multiple stakeholder relationship configurations, representing their 'power' and 'interest' (Frooman, 1999). As mentioned, this resulted in stakeholder configurations which were dynamic (changed during the innovation process) and required elastic (combined) stakeholder management strategies for each stakeholder type. This suggests the need for SMEs to develop adaptive capabilities (Wang and Ahmed, 2007) to manage external stakeholder relationships and leverage the benefits of OI.

\section{Conclusions}

Our findings respond to research by Spithoven et al., (2012), Vanhaverbeke, (2017) and Van de Vrande et al., (2009) by providing new insights into the dynamic stakeholder relationships involved in SME-OI which, to-date, have been underexplored. We also advance stakeholder theory (as called by Freeman, 2010) by operationalising key stakeholder constructs in an SME-OI context. We illustrate the importance of stakeholder power, contingency and dependency during OI and the need to combine existing stakeholder theories to understand stakeholder relationships during OI. We do this through our empirical findings which demonstrate the need for stakeholder models to recognise both the dynamic and elastic nature of SME-OI stakeholder management strategies which vary across different stages of the innovation process. We extend OI literature by providing a novel application of stakeholder mapping and stakeholder management tools to help understand both the role of varying stakeholders during OI processes and the different strategies that can be used to manage stakeholders of different types. Furthermore, through our framework presented in Annex 3, we extend OI literature by identifying the specific stakeholders SMEs engage with across the innovation processes and identify the challenges, liabilities and virtues of SMEs engagement in OI.

Our research also has several practical implications which will aid SME managers during their OI processes. First, we provide a mapping tool (Figure 1) and a guide of 
stakeholder configurations (Annex 2). Second, we provide SME managers with insights into the application of these tools. Our findings will help mitigate risk of contingent incompatible relationships. Third, we identify that SMEs may need more than one partner and that partner relationships may change during the innovation process. Thus, SMEs should regularly review and revise their OI strategy at each stage of the innovation process accordingly. SMEs should ensure strategic and contractual flexibility to not get locked into a particular relationship, as strict contracts can lead to strategic drift (Tidd \& Bessant, 2013), which was particularly prevalent in the cases of SME-LE OI. Furthermore, our findings highlight the importance of 'elastic' strategies for SME-OI stakeholder management to account for changes in stakeholder dynamics over time. This was particularly pertinent for experts/expert communities and investor relationships where SMEs and their stakeholders often have common interests but different objectives.

Based on our findings, there are several avenues for future research. Whilst the models of Friedman and Miles (2002), Frooman, (1999) and Freeman (1990) were applicable to understand the cases OI stakeholder relationships, future research should adopt a longitudinal and/or quantitative methodology to further validate the concepts, allow for statistical generalisation and to facilitate comparison of results with groups of LEs engaging in OI. The cases selected were SMEs engaged in successful processes of mainly inbound OI, therefore future insights into relationship dynamics of failed OI and/or outbound OI will advance theory and practice further. Future studies could also explore internal pressures and decision-making processes during OI engagement. It would be interesting to explore the internal and external stakeholder dynamics at individual, organisational and inter-organisational levels of analysis (Bogers et al., 2017; Glynn, 1996). Whilst it was not the focus of our study, we acknowledge that different institutional characteristics and regional settings (Karlsson \& Olsson, 2014) may affect OI processes. Thus, future research could adopt a quantitative analysis to measure the 
influence of macro-level factors on OI processes and stakeholder engagement strategies. Future research could also explore the perceptions of risk and how this may influence engagement in OI by SMEs compared to large companies.

\section{References}

Adams, R., Bessant, J., \& Phelps, R. (2006). Innovation management measurement: A review. International Journal of Management Reviews, 8(1), 21-47.

Archer, M. S. (1995). Realist Social Theory: The Morphogenetic Approach. In The morphogenetic approach. https://doi.org/papers3://publication/doi/10.1017/cbo9780511557675

Badillo, E. R., Galera, F. L., \& Moreno Serrano, R. (2017). Cooperation in R\&D, firm size and type of partnership. European Journal of Management and Business Economics, 26(1), 123-143. https://doi.org/10.1108/ejmbe-07-2017-008

Bessant, J., \& Tidd, J. (2015). Innovation and Entrepreneurship (3rd ed.). John Wiley \& Sons.

Bogers, M., Zobel, A.-K., Afuah, A., Almirall, E., Brunswicker, S., Dahlander, L., ... Ter Wal, A. L. J. (2017). The open innovation research landscape: established perspectives and emerging themes across different levels of analysis. Industry and Innovation, 24(1), 8-40. https://doi.org/10.1080/13662716.2016.1240068

Brunswicker, S., \& Vanhaverbeke, W. (2014). Open Innovation in Small and Medium-Sized Enterprises (SMEs): External Knowledge Sourcing Strategies and Internal Organizational Facilitators. Journal of Small Business Management, 53(4), 1241-1263. https://doi.org/10.1111/jsbm.12120

Burns, B. L., Barney, J. A. Y. B., Angus, R. W., \& Herrick, H. N. (2016). Enrolling stakeholders under conditions of risk and uncertainty. Strategic Entrepreneurship Journal, 106(October 2015), 97-106. https://doi.org/10.1002/sej

Buysse, K., \& Verbeke, A. (2003). Proactive environmental strategies: astakeholder management perspective. Strategic Management Journal, 24(5), 453-470. https://doi.org/10.1002/smj.299

Cassell, C., \& Symon, G. (2004). Essential Guide to Qualitative Methods in Organizational Research. https://doi.org/Book 
Chesbrough, H. (2003). Open Innovation The New Imperative for Creating and Profiting from Technology Xerox PARC The Achievements and Limits of Closed Innovation. Harvard Business School Press, 1-10. https://doi.org/10.1111/j.1467-8691.2008.00502.x

Chesbrough, H. (2006). Open Innovation: The New Imperative for Creating and Profiting from Technology. Retrieved from https://books.google.fi/books?id=OeLIH89YiMcC

Chesbrough, H., \& Brunswicker, S. (2014). A Fad or a Phenomenon? The Adoption of Open Innovation Practices in Large Firms. Research Technology Management, 57(2), p16-25. https://doi.org/10.5437/08956308X5702196

Chesbrough, Henry, \& Bogers, M. (2014). Explicating Open Innovation: Clarifying an Emerging Paradigm for Understanding Innovation Keywords. New Frontiers in Open Innovation, 1-37. https://doi.org/10.1093/acprof

Chesbrough, Henry, \& Brunswicker, S. (2013). Managing open Innovation in Large firms. EXECUTIVE SURVEY ON OPEN INNOVATION 2013, FRAUNHOFER VERLAG.

Chesbrough, Henry W. (2007). Why companies should have Open Business Models? MIT Sloan Management Review, 48(2), 22-28. https://doi.org/10.1111/j.1540-5885.2008.00309_1.x

Cohen, W. M., \& Levinthal, D. A. (1990). Absorptive Capacity: A New Perspective on Learning and Innovation. Administrative Science Quarterly, 35(1), 128. https://doi.org/10.2307/2393553

Cosh, A., \& Jin Zhang, J. (2012). Ambidexterity and open innovation in small and medium sized firms (SMEs). Proceedings of the Open Innovation: New Insights and Evidence Conference, 2526. London: Imperial College London.

Darnall, N., \& Henriques, I. (2010). Adopting proactive environmental strategy: the influence of stakeholders and firm size. Journal of Management Studies, 47(10), 1072-1094. https://doi.org/10.1111/j.1467-6486.2009.00873.x

Dooley, L., Kenny, B., \& Cronin, M. (2016). Interorganizational innovation across geographic and cognitive boundaries: does firm size matter? R\&D Management, 46(S1), 227-243.

Douma, M. (1997). Strategic Alliances: Fit or Failure. University of Twente, Enschede. European Commission. (2017). European Innovation Scoreboard 2017. In European Innovation Scorecard. https://doi.org/10.2873/571375 
European Commission. (2018). What is an SME? Retrieved from

http://ec.europa.eu/growth/smes/business-friendly-environment/sme-definition_en

Frankenberger, K., Weiblen, T., \& Gassmann, O. (2014). The antecedents of open business models : an exploratory study of incumbent firms [ Karolin Frankenberger Tobias Weiblen Oliver Gassmann ]. 1-33. Retrieved from https://www.alexandria.unisg.ch/Publikationen/nachInstitut/ITEM/230319

Freeman, E. R. (1984). Strategic management: A stakeholder approach (First edit). Harpercollins College Div.

Freeman, R. E. (2010). Strategic Management: A Stakeholder Approach. Retrieved from https://books.google.fi/books?id=NpmA_qEiOpkC

Friedman, A. L., \& Miles, S. (2002). Developing stakeholder theory. Journal of Management Studies, 39(January), 1-21.

Frooman, J. (1999). STAKEHOLDER INFLUENCE STRATEGIES. 24(2).

Glaser, B. (1992). Basics of Grounded Theory Analysis. Mill Valley CA: Sociology Press.

Glynn, M. A. (1996). Innovative genius: A framework for relating individual and organizational intelligences to innovation. The Academy of Management Review, 21(4), 1081-1111.

Goldkuhl, G., \& Cronholm, S. (2010). Adding Theoretical Grounding to Grounded Theory: Toward Multi-Grounded Theory. International Journal of Qualitative Methods, 9(2), 187-205. https://doi.org/10.1177/160940691000900205

Goldkuhl, G., \& Cronholm, S. (2018). Reflection/Commentary on a Past Article: “Adding Theoretical Grounding to Grounded Theory: Toward Multi-Grounded Theory.” International Journal of Qualitative Methods, 17(5), 1-5. https://doi.org/10.1177/160940691000900205

Gould, R. W. (2012). Open Innovation and Stakeholder Engagement. 7(3), 1-11.

Graham, S. (2017). The Influence of External and Internal Stakeholder Pressures on the Implementation of Upstream Environmental Supply Chain Practices. Business \& Society, 1-33. https://doi.org/10.1177/0007650317745636

Han, K., Oh, W., Im, K. S., Chang, R. M., Oh, H., \& Pinsonneault, A. (2012). Value cocreation and wealth spillover in open innovation alliances. MIS Quarterly, 36(1), 1-26. 
Harryson, S. J. (1997). How Canon and Sony drive product innovation through networking and application- focused R\&D. Journal of Product Innovation Management, 14(4), 288-295.

Hewitt-Dundas, N., \& Roper, S. (2018). Exploring market failures in open innovation. International Small Business Journal: Researching Entrepreneurship, 36(1), 23-40. https://doi.org/10.1177/0266242617696347

Hossain, M., \& Kauranen, I. (2016). Open innovation in SMEs: a systematic literature review. Journal of Strategy and Management, 9(1), 58-73. https://doi.org/10.1108/JSMA-08-2014-0072 Huggins, R. (2008). Universities and knowledge-based venturing: finance, management and networks in London. Entrepreneurship \& Regional Development, 20(2), 185-206. https://doi.org/10.1080/08985620701748342

Huggins, R., \& Thompson, P. (2015). Entrepreneurship, innovation and regional growth: a network theory. Small Business Economics, 45(1), 103-128. https://doi.org/10.1007/s11187-015-9643-3

Huston, L., \& Sakkab, N. (2006). Connect and Develop Inside Procter \& Gamble's New Model for Innovation. Harvard Business Review, 84(3), 58-66.

Jeffrey, H., \& Dyer, J. H. (1998). The relational view: Cooperative strategy and sources of interorganizational competitive advantage. The Academy of Management Review, 23(4), 660679.

Jeppesen, L. B., \& Molin, M. J. (2003). Consumers as Co-developers: Learning and Innovation Outside the Firm. Technology Analysis \& Strategic Management ISSN:, 15(3), 363-383. https://doi.org/10.1080/09537320310001601531

Karlsson, C., \& Olsson, O. (2014). Product Innovation in Small and Large Enterprises Product Innovation in Small and Large Enterprises. Small Business Economics, 10(1), 31-46. https://doi.org/10.1023/A

Kaufmann, H. R., \& Shams, S. M. R. (2015). Entrepreneurial challenges in the 21st century: creating stakeholder value co-creation. Hampshire, UK: Palgrave Macmillan.

Laursen, K., \& Salter, A. (2006). Open for innovation: The role of openness in explaining innovation performance among U.K. manufacturing firms. Strategic Management Journal, 27(2), 131-150. https://doi.org/10.1002/smj.507 
Lee, S., Park, G., Yoon, B., \& Park, J. (2010). Open innovation in SMEs — An intermediated network model. Research Policy, 39(2), 290-300. https://doi.org/10.1016/j.respol.2009.12.009

Limaj, E., \& Bernroider, E. (2017). The roles of absorptive capacity and cultural balance for exploratory and exploitative innovation in SMEs. Journal of Business Research, $X X(\mathrm{XX})$, xxxxxx.

Markovic, S., \& Bagherzadeh, M. (2018). How does breadth of external stakeholder co-creation influence innovation performance? Analyzing the mediating roles of knowledge sharing and product innovation. Journal of Business Research, 88(September 2017), 173-186. https://doi.org/10.1016/j.jbusres.2018.03.028

Mcadam, M., Miller, K., \& Mcadam, R. (2016). Situated regional university incubation: A multi-level stakeholder perspective. Technovation, 50-51, 69-78. https://doi.org/10.1016/j.technovation.2015.09.002

Miles, S. (2017). Stakeholder Theory Classification: A Theoretical and Empirical Evaluation of Definitions. Journal of Business Ethics, 142(3), 437-459. https://doi.org/10.1007/s10551-015$2741-y$

Olander, H., Hurmelinna-Laukkanen, P., \& Mähönen, J. (2009). What's small size got to do with it? Protection of intellectual assets in SMEs. International Journal of Innovation Management, 13(03), 349-370. https://doi.org/10.1142/s1363919609002339

Ortega-Argilés, R., Vivarelli, M., \& Voigt, P. (2009). R\&D in SMEs: A paradox? Small Business Economics, 33(1), 3-11. https://doi.org/10.1007/s11187-009-9187-5

Patton, M. (1990). Designing Qualitative Studies. Purpuseful sampling. In Qualitative Evaluation and Research Methods (pp. 169-186). https://doi.org/10.1002/nur.4770140111

Popa, S., Soto-Acosta, P., \& Martinez-Conesa, I. (2017). Antecedents, moderators, and outcomes of innovation climate and open innovation: An empirical study in SMEs. Technological Forecasting \& Social Change, 118(2017), 134-142.

https://doi.org/10.1016/j.techfore.2017.02.014

Presenza, A., \& Meleddu, M. (2017). Small-and medium-scale Italian winemaking companies facing the open innovation challenge. International Small Business Journal, 35(3), 327-348. 
https://doi.org/10.1177/0266242616664798

Pullen, A. J. J., De Weerd-Nederhof, P. C., Groen, A. J., \& Fisscher, O. A. M. (2012). Open innovation in practice: Goal complementarity and closed NPD networks to explain differences in innovation performance for SMEs in the medical devices sector. Journal of Product Innovation Management, 29(6), 917-934. https://doi.org/10.1111/j.1540-5885.2012.00973.x

Radas, S., Anić, I. D., Tafro, A., \& Wagner, V. (2015). The effects of public support schemes on small and medium enterprises. Technovation, 38, 15-30. https://doi.org/10.1016/j.technovation.2014.08.002

Rothwell, R. (1994). The changing nature of the innovation process: implications for SMEs. In New Technology-Based Firms in the 1990s (pp. 11-21). London: Paul Chapman.

Rothwell, Roy, \& Dodgson, M. (1991). External linkages and innovation in small and medium- sized enterprises. $R \& D$ Management, 21(2), 125-138. https://doi.org/10.1111/j.14679310.1991.tb00742.x

Siegel, D. S., \& Vitaliano, D. F. (2007). An Empirical Analysis of the Strategic Use of Corporate Social Responsibility. Journal of Economics \& Management Strategy, 16(3), 773-792.

Spithoven, A., Vanhaverbeke, W., \& Roijakkers, N. (2012). Open innovation practices in SMEs and large enterprises. Small Business Economics, 41(3), 537-562. https://doi.org/10.1007/s11187012-9453-9

Street, C. T., \& Cameron, A.-F. (2007). External Relationships and the Small Business: A Review of Small Business Alliance and Network Research. Journal of Small Business Management, 45(2), 239-266. Retrieved from http://www.blackwell-synergy.com/doi/abs/10.1111/j.1540627X.2007.00211.X

Teece, D. J. (1986). Profiting from technological innovation: Implications for integration, collaboration, licensing and public policy. Research Policy, 15(6), 285-305.

Teplov, R., Albats, E., \& Podmetina, D. (2018). What Does Open Innovation Mean? Business Versus Academic Perceptions. International Journal of Innovation Management. https://doi.org/10.1142/S1363919619500026

Tidd, J., \& Bessant, J. (2013). Integrating Technological, Market and Organizational Change. In 
Managing Innovation: 5th edition. https://doi.org/10.1145/944868.944913

Tidd, J., Bessant, J., \& Pavitt, K. (2001). Managing Innovation - Integrating Technological, Market and Organizational Change. Managing Innovation: Integrating Technological, Market and Organizational Change, pp. 197-238. https://doi.org/10.1016/S0166-4972(98)80033-3

Trott, P., \& Hartmann, D. (2009). Why "open innovation" is old wine in new bottles. International Journal of Innovation Management, 13(4), 715-736. Retrieved from http://www.worldscinet.com/abstract?id=pii:S1363919609002509

Van de Vrande, V., De Jong, J. P., Vanhaverbeke, W., \& De Rochemont, M. (2009). Open innovation in SMEs: Trends, motives and management challenges. Technovation, 29(6), 423-437. https://doi.org/10.1016/j.technovation.2008.10.001

Vanhaverbeke, W. (2017). Managing Open Innovation in SMEs. Cambridge: Cambridge University Press.

Vanhaverbeke, W., \& Cloodt, M. (2014). Theories of the Firm and Open Innovation. In Henry William Chesbrough, W. Vanhaverbeke, \& J. West (Eds.), New Frontiers in Open Innovation (pp. 256-278). Oxford University Press.

Weiblen, T. (2014). The Open Business Model: Understanding an Emerging Concept. Journal of Multi Business Model Innovation and Technology, 2(1), 35-66. https://doi.org/10.13052/jmbmit2245-456X.212

West, J., \& Bogers, M. (2013). Leveraging External Sources of Innovation: A Review of Research on Open Innovation. Journal of Product Innovation Management, 31(4), 814-831. https://doi.org/10.1111/jpim.12125

Wickert, C., Scherer, A. G., \& Spence, L. J. (2016). Walking and Talking Corporate Social Responsibility: Implications of Firm Size and Organizational Costs. Journal of Management Studies, 53(7), 1169-1196.

Wren, C., \& Storey, D. (2002). Evaluating the effect of soft business support upon small firm performance. Oxford Economic Papers, 54(2), 334-365. https://doi.org/10.1093/oep/54.2.334

Xie, X., Wang, L., \& Zeng, S. (2018). Inter-organizational knowledge acquisition and firms' radical innovation: A moderated mediation analysis. Journal of Business Research, 90(April), 295-306. 
https://doi.org/10.1016/j.jbusres.2018.04.038

Yeaple, R. N. (1992). Why are small R\&D organizations more productive? IEEE Transactions on Engineering Management, 39(4), 332-346. 


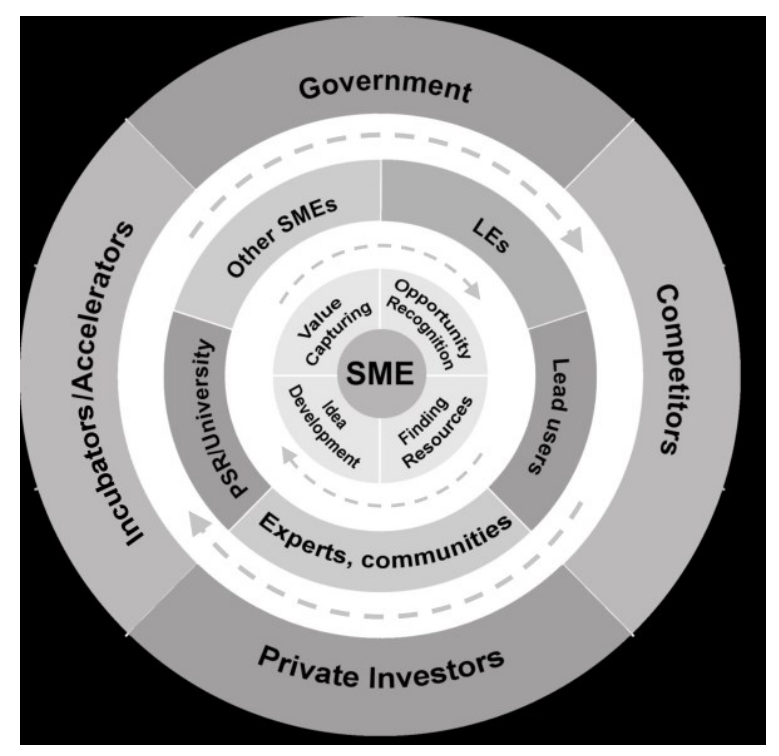

Figure 1 - SME-OI Stakeholder Framework (based on Freeman 2010; Presenza \& Meleddu 2017; Brunswicker \& Vanhaverbeke 2014; Vanhaverbeke 2017; Bessant \& Tidd 2015)

Table 1 - Institutional configurations with associated situational logic and strategic actions (Friedman and Miles, 2002 adapted from Archer 1995)

\begin{tabular}{|c|c|c|c|}
\hline \multicolumn{4}{|c|}{ Archer's institutional configurations } \\
\hline & & \multicolumn{2}{|c|}{ Connections (purpose) } \\
\hline & & Necessary & Contingent \\
\hline \multirow{2}{*}{$\begin{array}{l}\text { Set of ideas and/or } \\
\text { structures of material } \\
\text { interests }\end{array}$} & Compatible & $\begin{array}{c}\mathbf{A} \\
\text { Protectionist } \\
\text { Defensive }\end{array}$ & $\begin{array}{c}\text { B } \\
\text { Opportunism } \\
\text { Opportunistic }\end{array}$ \\
\hline & Incompatible & $\begin{array}{c}\text { D } \\
\text { Concessionary } \\
\text { Compromise } \\
\end{array}$ & $\begin{array}{l}\text { C } \\
\text { Competition } \\
\text { Elimination } \\
\end{array}$ \\
\hline \multicolumn{4}{|c|}{ Configurations of Archer's Model } \\
\hline \multicolumn{2}{|l|}{ Configuration } & $\begin{array}{c}\text { Situational Logic (Stakeholder } \\
\text { relationship dynamic) }\end{array}$ & $\begin{array}{c}\text { Strategic Action (stakeholder } \\
\text { management strategies) }\end{array}$ \\
\hline \multicolumn{2}{|l|}{ A Necessary compatible } & Protectionist & Defensive \\
\hline \multicolumn{2}{|l|}{ B Contingent compatible } & Opportunism & Opportunistic \\
\hline \multicolumn{2}{|c|}{ C Contingent incompatible } & Competition & Elimination \\
\hline \multicolumn{2}{|c|}{ D Necessary incompatible } & Concessionary & Compromise \\
\hline
\end{tabular}

Table 2 - Typology of influence Strategies (Frooman, 1999)

\begin{tabular}{|cc|c|c|}
\hline & & \multicolumn{2}{|c|}{ Is the stakeholder dependent on the firm? } \\
\cline { 2 - 4 } & NO & YES \\
\hline
\end{tabular}


Table 3 - Overview of the case studies

\begin{tabular}{|c|c|c|c|c|c|c|}
\hline Case\# & Sector & Country & $\begin{array}{l}\text { Age: } \text { year } \\
\text { established }\end{array}$ & $\begin{array}{l}\text { Size: } \\
\text { number of } \\
\text { employees }\end{array}$ & OI partnerships & $\begin{array}{l}\text { Interviewee(s) } \\
\text { position }\end{array}$ \\
\hline $\bar{A}$ & $\begin{array}{l}\text { LMT } \\
\text { Manuf. }\end{array}$ & DK & 2007 & 9 & $\begin{array}{l}\text { Developing a prototype with a } \\
\text { research institute; analysing the } \\
\text { market with a university; spin-off }\end{array}$ & CEO-founder \\
\hline B & HT Manuf. & DK & 2015 & 5 & $\begin{array}{l}\text { Crowd-science with lead users, } \\
\text { experts, OS platforms, communities }\end{array}$ & CEO-founder \\
\hline $\mathrm{C}$ & HT Serv. & FI & 2007 & 6 & $\begin{array}{l}\text { Involving LE, lead customers, other } \\
\text { SMEs, city municipality, experts in } \\
\text { innovation development }\end{array}$ & $\begin{array}{l}\text { CEO-founder } \\
\text { Co-founder/chief } \\
\text { developer }\end{array}$ \\
\hline $\mathrm{D}$ & HT Serv. & FI & 2007 & 32 & $\begin{array}{l}\text { Collaboration with LE-client and } \\
\text { other external actors }\end{array}$ & CEO-co-founder \\
\hline$E$ & HT Manuf. & FI & 2006 & 175 & $\begin{array}{l}\text { Concept development, product } \\
\text { design with university. } \\
\text { Manufacturing with an engineering } \\
\text { SME }\end{array}$ & CTO \\
\hline $\mathrm{F}$ & LMT Serv. & FI & 2015 & 11 & $\begin{array}{l}\text { Collaboration with university, LE, } \\
\text { other SME in business development }\end{array}$ & CEO-founder \\
\hline G & HT Serv. & FI & 2000 & 4 & $\begin{array}{l}\text { Collaboration with multiple partners } \\
\text { (LE, other SME, university, experts) } \\
\text { in business model development }\end{array}$ & CEO-co-founder \\
\hline $\mathrm{H}$ & LMT Serv. & FI & 2009 & 2 & $\begin{array}{l}\text { Collaboration with experts in } \\
\text { creating and capturing value }\end{array}$ & CEO-founder \\
\hline I & LMT Serv. & No & 2000 & 6 & $\begin{array}{l}\text { Collaboration with university, } \\
\text { European Association, experts in } \\
\text { service development and digital } \\
\text { learning }\end{array}$ & CEO-founder \\
\hline $\mathrm{J}$ & LMT Serv. & $\mathrm{NL}$ & 2012 & 2 & $\begin{array}{l}\text { Collaboration with universities, } \\
\text { SME, Health Care services in } \\
\text { identifying customer needs, } \\
\text { technology and business concept, } \\
\text { product trials }\end{array}$ & $\begin{array}{l}\text { Founders }+ \\
\text { consultants }\end{array}$ \\
\hline $\mathrm{K}$ & HT Manuf. & $\mathrm{NL}$ & 2009 & 30 & $\begin{array}{l}\text { Collaboration with experts, LE, } \\
\text { other SMEs in technology, product } \\
\text { and business development }\end{array}$ & CEO \\
\hline
\end{tabular}

Table 4 -A synopsis of the coding process

\begin{tabular}{|c|c|c|c|c|c|c|}
\hline \multirow[b]{2}{*}{ Stakeholder } & \multirow{2}{*}{$\begin{array}{l}\text { Innovation } \\
\text { stage }\end{array}$} & \multirow[b]{2}{*}{ Open codes } & \multicolumn{2}{|c|}{$\begin{array}{l}\text { SME-stakeholder } \\
\text { interdependencies }\end{array}$} & \multicolumn{2}{|c|}{ Balancing Mechanisms } \\
\hline & & & $\begin{array}{l}\text { First-order } \\
\text { categories }\end{array}$ & $\begin{array}{l}\text { Second-order } \\
\text { themes }\end{array}$ & $\begin{array}{l}\text { First-order } \\
\text { categories }\end{array}$ & $\begin{array}{l}\text { Second- } \\
\text { order } \\
\text { themes }\end{array}$ \\
\hline $\mathrm{LE}=$ customer & $\begin{array}{l}\text { Finding } \\
\text { resources } \\
\& \\
\text { capturing } \\
\text { value }\end{array}$ & $\begin{array}{l}\text { They paid the initial sum } \\
\text { Too strong focus on } \\
\text { customers' needs hinder } \\
\text { future developments as it } \\
\text { locks the company } \\
\text { resources } \\
\text { Have a global } \\
\text { perspective from the very } \\
\text { first customer }\end{array}$ & $\begin{array}{l}\text { Large clients - } \\
\text { sources of } \\
\text { revenue/R\&D } \\
\text { funding } \\
\text { Focusing on a } \\
\text { single customer } \\
\text { is dangerous }\end{array}$ & $\begin{array}{l}\text { Resource- } \\
\text { dependency } \\
\& \text { resource } \\
\text { lock-in }\end{array}$ & $\begin{array}{l}\text { While } \\
\text { serving a } \\
\text { single } \\
\text { customer still } \\
\text { develop an } \\
\text { eco-system }\end{array}$ & $\begin{array}{l}\text { Eco- } \\
\text { system } \\
\text { approach }\end{array}$ \\
\hline
\end{tabular}


Annex 1: Inductive/data-driven coding

Themes
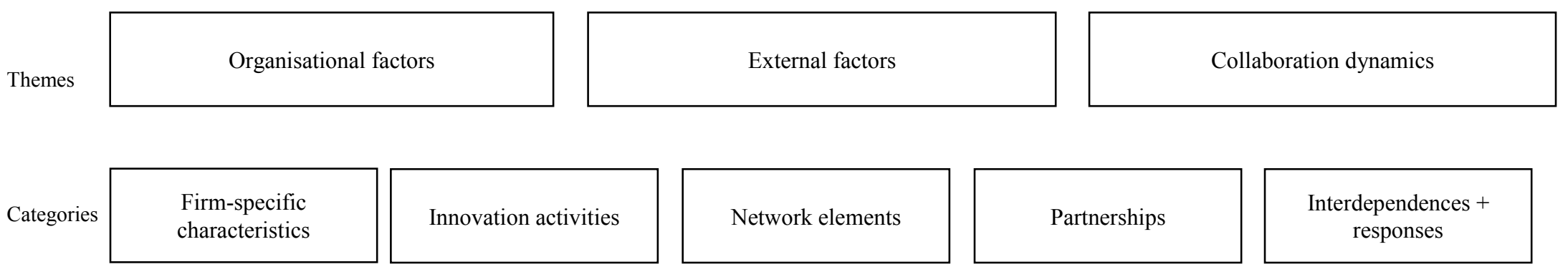

Interdependences +

responses

\begin{tabular}{|c|c|}
\hline $\begin{array}{l}\text { Sub- } \\
\text { categories }\end{array}$ & $\begin{array}{l}\text { - Size } \\
\text { - Support } \\
\text { - } \text { Funding } \\
\text { - } \text { Business background } \\
\text { - IT capabilities } \\
\text { - Market }\end{array}$ \\
\hline
\end{tabular}

- Accessibility
- Innovation systems
- Complexity of business
- Infoximity
- Info sharing

- Network embeddedness
- Network activity
- Open source network
- Incubtomer involvement
- Personal Characteristics

- Partners

- Collaboration

- Interdependence + response

- University Collaboration

- Supplier / buyer assessment

indicators

- IP and patent application

\begin{tabular}{|c|c|}
\hline $\begin{array}{l}\text { Examples } \\
\text { of open } \\
\text { codes }\end{array}$ & $\begin{array}{ll}\text { - } & \text { Personal background in academia } \\
\text { - } & \text { Adopt to need } \\
\text { - } & \text { Requirements for collaboration } \\
\text { - } & \text { Trust } \\
\text { - } & \text { Focus on R\&D } \\
\text { - } & \text { Sales orientation } \\
\text { - } & \text { Sales performance } \\
\text { - } & \text { supportive to solve lack of } \\
\text { - } & \text { proximity } \\
\text { - } & \text { Funding opportunities } \\
\text { - } & \text { Carrier for joint marketing } \\
& \text { approaches }\end{array}$ \\
\hline
\end{tabular}

- Need for collaboration

- Alternative strategy

- Access to knowledge / skills + network

- Chance to benefit from knowledge expertise / creativity

- Access to knowledge and facilities

- Source of knowledge

- Impact on collaboration strategies

- Open minded attitude
- Improve business skills (especially non-MBA background entrepreneurs)

- Supportive to contact and collaboration

- Negative impact on univ-SME collaboration

- Status + trustworthiness to other companies

- Impact on development stage

- Partner fit

- Supportive to entrepreneurship and/or collaboration

- Amplification of activity (focus) 
Annex 2 - Summary of the results

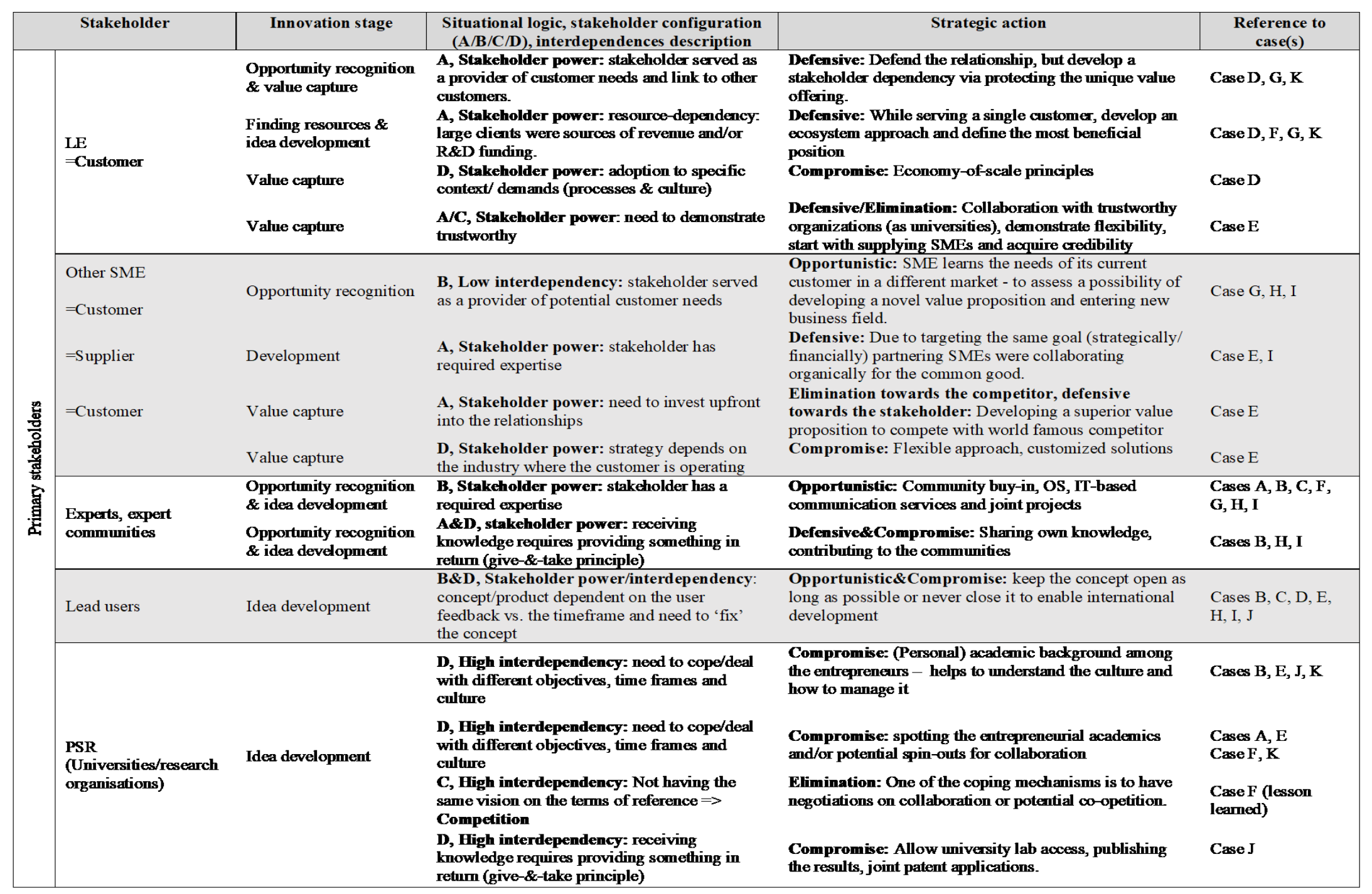


Government \& public

funded programmes

\section{Finding resources \&}

idea development

D, Stakeholder power: Access

funding/expertise in return of complyin

with the rules, which require resource
Compromise: Enabling a maximum complimentarily an overlap between the project co-funded by government and SME core business 
Annex 3 - SME-OI Framework: Stakeholder engagements, challenges, liabilities and virtues of smallness

\begin{tabular}{|c|c|c|c|c|}
\hline Stage & Stakeholder & Challenges & Liabilities and virtues of smallness in the strategies applied & Case(s) $^{1}$ \\
\hline \multirow{4}{*}{ 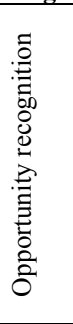 } & LE=customer & $\begin{array}{l}\text { Lock-in; Need to prove } \\
\text { credibility }\end{array}$ & $\begin{array}{l}\text { Liabilities: LE stakeholder power due to resource dependencies } \\
\text { Virtues: compatibility with other SMEs allows gaining credibility and efficient resource } \\
\text { complementarity; a USP of the SME as a source of LEs' innovation }\end{array}$ & D G K \\
\hline & $\mathrm{SME}=$ customer & Not identified & Virtues: low stakeholder interdependency allows opportunistic learnings & G H I \\
\hline & $\begin{array}{l}\text { Experts, } \\
\text { communities }\end{array}$ & $\begin{array}{llr}\text { Dependency } & \text { on } & \text { expert } \\
\text { knowledge; } & \text { Need } & \text { for } \\
\text { reciprocal contribution } & & \\
\end{array}$ & $\begin{array}{l}\text { Liabilities: stakeholder power due to expertise dependencies } \\
\text { Virtues: propensity for informal collaboration; absence of bureaucratic barriers }\end{array}$ & $\begin{array}{l}\text { A B C F } \\
\mathrm{H}\end{array}$ \\
\hline & Competitors & \begin{tabular}{lc} 
High & \multicolumn{2}{c}{ interdependency } \\
especially & if market is \\
immature
\end{tabular} & $\begin{array}{l}\text { Virtues: abilities to be fast and flexible to be first in differentiating the offering and taking the vacant } \\
\text { market needs; acquiring (even smaller) competitors }\end{array}$ & B F I \\
\hline \multirow{3}{*}{ 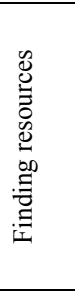 } & LE=customer & Lock-in & $\begin{array}{l}\text { Liabilities: LE stakeholder power due to resource dependencies } \\
\text { Virtues: only in case of proactive strategic thinking, a fresh/disruptive SME' approach to the market } \\
\text { situation and subsequent development of an ecosystem may allow a flip around to power dependencies }\end{array}$ & F G K \\
\hline & Government & $\begin{array}{lrr}\begin{array}{l}\text { Complying } \\
\text { programme } \\
\text { requith } \\
\text { rules, }\end{array} & \begin{array}{r}\text { the } \\
\text { which }\end{array} \\
\end{array}$ & $\begin{array}{l}\text { Liabilities: resource dependency } \\
\text { Virtues: awareness of the strategic importance of SMEs for economy development and thus continuous } \\
\text { growth and development of the governmental instruments supporting SMEs }\end{array}$ & $\begin{array}{l}\text { C F G J } \\
\mathrm{K}\end{array}$ \\
\hline & Investors & $\begin{array}{l}\text { Need to prove } \\
\text { investors' } \\
\text { orientation }\end{array}$ & Liabilities: high resource dependency; need to integrate short-term goals to satisfy investors & $\begin{array}{l}\text { A B E F } \\
\text { G }\end{array}$ \\
\hline \multirow{7}{*}{ 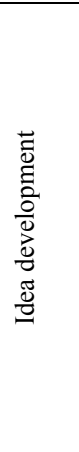 } & $\mathrm{LE}=$ Customer & Lock-in & $\begin{array}{l}\text { Liabilities: LE stakeholder power due to resource } \\
\text { Virtues: a USP of the SME as a source of LEs' in }\end{array}$ & $\mathrm{K}$ \\
\hline & SME=Supplier & $\begin{array}{l}\text { Dependency on partner } \\
\text { expertise }\end{array}$ & $\begin{array}{l}\text { Liabilities: stakeholder power due to expertise dependencies } \\
\text { Virtues: compatibility with other SMEs; ability to transform dependency to inter-dependency }\end{array}$ & E I \\
\hline & $\begin{array}{l}\text { Experts, } \\
\text { communities }\end{array}$ & $\begin{array}{llr}\text { Dependency } & \text { on } & \text { expert } \\
\text { knowledge; } & \text { Need } & \text { for } \\
\text { reciprocal contribution } & \end{array}$ & $\begin{array}{l}\text { Liabilities: stakeholder power due to expertise dependencies } \\
\text { Virtues: propensity for informal collaboration; absence of bureaucratic barriers; SME USP and its value } \\
\text { for the expert community development }\end{array}$ & $\begin{array}{l}\text { A B C F } \\
\text { G H I }\end{array}$ \\
\hline & Lead users & $\begin{array}{l}\text { Dependency on user feedback } \\
\text { vs. time pressure }\end{array}$ & $\begin{array}{l}\text { Liabilities: lack of resources and scale } \\
\text { Virtues: agility and possibility to keep the concept 'open' }\end{array}$ & $\begin{array}{l}\text { B C D E } \\
\text { HIJ } \\
\end{array}$ \\
\hline & PSR & $\begin{array}{l}\text { Different objectives, time } \\
\text { frames and culture }\end{array}$ & $\begin{array}{l}\text { Liabilities: short-term business orientation } \\
\text { Virtues: SME USP; expertise/technology which has a scientific potential }\end{array}$ & $\begin{array}{l}\text { A B E F } \\
\text { GIJK }\end{array}$ \\
\hline & Government & Complying with regulations & Liabilities: stakeholder power due to expertise dependencies & CI \\
\hline & Incub., acceler. & $\begin{array}{l}\text { Need for reciprocal } \\
\text { contribution }\end{array}$ & Virtues: eligibility due to size; low stakeholder interdependency allows opportunistic learnings & B CF \\
\hline \multirow{2}{*}{ 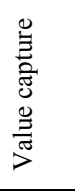 } & LE $=$ Customer & Lock-in & $\begin{array}{l}\text { Liabilities: LE stakeholder power due to resource dependencies } \\
\text { Virtues: only in cases where there is proactive strategic thinking; a fresh/disruptive SME' approach to } \\
\text { the market situation and subsequent development of an ecosystem may allow a flip around te power } \\
\text { dependencies }\end{array}$ & D G \\
\hline & SME=Customer & Customer power & $\begin{array}{l}\text { Liabilities: play an all-or-nothing game } \\
\text { Virtues: compatibility with other SMEs in terms of }\end{array}$ & E \\
\hline
\end{tabular}

${ }^{1}$ As this study does not aim at generalization, but rather at the exploration of the SME-OI phenomenon, the references to the relevant cases studied are kept here to highlight the relativity and contextual dependency of these observations. 